\title{
Nothing for Money and Your Work for Free: Internships and the Marketing of Higher Education
}

\author{
Mara Einstein \\ Queens College, City University of New York, Flushing, New York, USA, \\ Mara.Einstein@qc.cuny.edu
}

\begin{abstract}
American universities have significantly increased their marketing expenditures over the last decade. The high cost of education, reductions in government funding, and precipitous declines in the traditional college-aged population (18-21 year olds) are some of the key factors forcing universities to be more aggressive with the promotional techniques they use to attract prospective students. In this competitive marketplace, schools promote the attributes they believe will be most compelling to high schoolers and their parents, including academics, sports, campus life, and careers. Tied into this last factor is the promotion of internship opportunities. While some of these hands-on experiences lead to jobs, there are no guarantees that attending college and engaging in an internship will translate into fulltime employment. Using content analysis and auto-ethnography, I examine how universities use internships to market higher education, and argue that this is a particularly pernicious practice within the area of media studies.
\end{abstract}

Keywords: internships, marketing, college student recruitment, higher education, universities and colleges

Acknowledgements: I would like to thank the editors for seeing the promise of this piece in its early stages and to the reviewers who provided thoughtful, specific commentary. In addition, I would like to thank my student interns, my research assistant Marykate Byrnes, and my high school assistants, Victoria Stempel and Naomi Langer, who provided much needed texts for analysis.

Over the last two decades, internships have evolved from a voluntary learning experience to become what is perceived to be a mandatory step up the US career ladder (Shoenfelt, Stone and Kottke 2013; Knouse, Tanner and Harris 1999). Students, therefore, feel compelled to take on one or more internships during their college years. ${ }^{1}$ Simultaneously, changes in the higher education business environment have led universities to become more aggressive marketers. Employing an array of marketing tools and techniques such as branding, social media, and direct marketing, universities now sell their institutions to high school students and their parents in much the same way that consumer products are sold (Banet-Weiser 2013; LayHwa 2011; Hearn 2010; Black 2008; Brunzel 2007; Lowrie 2007). Specifically, higher education marketers identify the most important attributes and benefits their institution has to offer, learn the needs and wants of their target audience, and then promote these to prospective students. Thus, the promise of landing an internship becomes integral to marketing US universities to prospective students and their parents.

This article analyzes the convergence of higher education marketing and the internship economy. I start with a short examination of the changing business conditions that led to the proliferation of marketing in higher education and the industry that grew up around it. This is followed by a content analysis of university marketing materials with a specific focus on how internships are presented in direct marketing materials. Internships are most often promoted as

\footnotetext{
${ }^{1}$ Best estimates are that half of the 1.5 million annual internships in the United States are unpaid. However, that figure is suspect as unpaid internships are frequently illegal and employers have no incentive to report them (Howe 2014).
} 
a career or résumé-building tool with emphasis placed on access to famous alumnae and the breadth of opportunities available, or as an aspect of co-op or experiential learning, which is more focused on learning in the present rather than money-making in the future. I conclude by reflecting on internships within the media industry, based on my 15-year experience administering a college internship program within a media studies department as well as my 20 years of experience marketing major television networks and working at advertising agencies, where I often hired and worked with university interns. As other scholars have noted, while these on-the-job opportunities give students first-hand experience, they rarely come with a paycheque or the guarantee of a future job assignment, particularly in the "glamour industries" of media and marketing (Frenette 2013; Perlin 2011; Frederick 1997). My central argument is that internships are a facile yet misleading attribute for promoting higher education; these pseudo-jobs are a tempting lure for young adults, yet they perpetuate the myth that a university education combined with an internship leads to full-time employment. In truth, internships are free labour for corporations, a moneymaker for universities, and, incredibly, a successful promotional tool to sell students on programs that provide these opportunities.

\section{Corporatization, Commoditization, and the Creation of a Competitive Marketplace}

Numerous scholars have written about the corporatization of higher education (Tuchman 2009; Woodhouse 2009; Bousquet 2008; Washburn 2006; Bok 2004; Steck 2003; Aronowitz 2001; Slaughter and Leslie 1997). They note the many ways that universities reflect their corporate counterparts, including employing an "academic temp system" where the university is made up of a continually reduced number of full-time workers in favour of part-time unprotected labour; implementing changes in funding structures that rely on "consumer purchases," and marrying curriculum to the market rather than societal needs, i.e., favouring practical, skills-based courses over the arts and humanities. Concomitant with corporatization is the commoditization of higher education-the transformation of distinguishable entities (universities) into homogeneous commodities (Reimann, Schilke and Thomas 2008)-and with that comes the increased use of marketing and promotion (Natale and Doran 2012; Twitchell 2005).

Universities became commodities because of changes in the business environment of higher education, particularly over the last three decades. Specifically, government funding moved from direct support of the institution to indirect support through students, i.e., providing financial aid. Some scholars peg this change to the Higher Education Act of 1965 (Heller 2011), others to the Nixon administration (Naidoo, Shankar and Veer 2011), but putting the burden of funding education squarely on the backs of students and their families became more fully the norm in the 1980s, when neoliberal philosophies prevailed (Mills 2012). Anya Kamenetz (2006) demonstrates the consequences of this shift when she notes, "In 1981, 45 percent of all federal undergraduate student aid came in loans, 52 percent in grants. By the end of the 1990s, the proportion was more than reversed; loans made up 58 percent of federal financial aid, and grants just 41 percent" (18). Thus, funding for universities increasingly became the responsibility of individuals who could rely less on grants, which do not have to be repaid, and more on loans, which most decidedly do. Today, more than half (57 percent) of students can expect to leave college with an average debt load of $\$ 24,000$-this in an economy where the starting salaries of many college students will be around $\$ 30,000$ a year if they are lucky enough to find a job. These statistics become ever more startling when understanding that the same education 30 years ago cost less than $\$ 6,000$ in current dollars (US Department of Education 2013). Rising tuition is exacerbated by American incomes remaining flat over the last several decades, making university tuition an ever-larger part of the household budget. Given this, it is not surprising that students and their parents are looking for a return on their investment (ROI). ROI translates into the ability to get a job immediately after graduation-a job that now will likely 
require a college-credit bearing internship. Therefore, higher education marketers make internships part of the recruitment effort.

As universities have become progressively tuition driven according to the State Higher Education Officers Association (Bidwell 2014), they have had to promote themselves directly to "consumers." ${ }^{2}$ Further driving the aggressive and competitive marketing is the annual rankings of US News \& World Report (Twitchell 2005; Meredith 2004; Monks and Ehrenberg 1999). This rating system began in the mid-1980s, and because parents, students, and guidance counsellors depend on the information it contains, institutions are obliged to increase their rankings in an attempt to entice more applicants and decrease their acceptance rate-a figure that makes the university appear more exclusive and ultimately more appealing. ${ }^{3}$ In addition to promoting exclusivity, universities market the majors offered, consumer-driven amenities like climbing walls and sports arenas, and, finally, the affinity they have with their alumni network and the expertise of the career center-valuable resources for internships and career counselling (Kirp 2004; Twitchell 2005). ${ }^{4}$

Compelled to increase enrolments because of reduced government spending as well as being measured based on quantitative corporate standards, considerable budgets are allocated to marketing. In the first half of 2013 , colleges spent $\$ 570.5$ million on advertising, with nonprofit institutions spending more than for-profit schools- $\$ 302$ million versus $\$ 268.5$ million respectively (Brock 2013). Some schools reportedly spent upwards of $\$ 5$ million on their advertising campaigns, though typically marketing budgets are a tenth of that amount (Miley $2009,6)$. Not included in these numbers is the monies spent on direct marketing-one of the most expensive forms of promotion, which must be considerable given the amount of mail these institutions disseminate. Whether direct mail or traditional brand advertising, it is estimated to have cost $\$ 2,143$ per student to recruit a prospect for a four-year college in 2013 (Noel-Levitz 2013).

But even these expenditures are unlikely to be enough to sustain universities moving forward. For a time, higher tuition combined with more people going to college assuaged the imbalance due to cuts in government spending, but no longer. Enrolment statistics in recent years are striking: while 15.3 million students went to college in 2000 , by 2012 the number was 21.6 million-more than ever before (US Department of Education n.d.). The recession played an important role in that increase because students enrolled in college either to upgrade their skills or because of lack of employment. Also, jobs that once required a high school education now require a college degree (Rampell 2013). In the last two years, however, enrolment figures have begun to decline (Bidwell 2013), which is likely due in some part to the precipitous declines in the traditional college-aged population. This cohort reached its peak in 2011, after which it had an abrupt decline and is not expected to return to current levels again until 2024 according to the Western State Commission for Higher Education (WICHE 2012). As the number of prospects decline, we can expect to see marketing - and the marketing of internship opportunities-intensify further still as universities increasingly compete for top traditional high school prospects as well as pursue "non-traditional" college students.

\footnotetext{
${ }^{2}$ In the last five years alone funding per student is down 26 percent and it is only in the last year that funding has begun to increase, though not enough to make up for years of losses (Belkin 2014).

${ }^{3}$ While universities market to students they want to join their freshman class, they also market to students who have little chance of getting into the school. The higher the number of applicants, the lower the acceptance percentage, which increases the school's ranking.

${ }^{4}$ Universities also compete against for-profit institutions and online college offerings, but this is beyond the scope of the current study.
} 


\subsection{The Business of Marketing and Branding Higher Education}

Higher education marketing is not a new phenomenon. Strategic business marketing was introduced into United States universities in the 1970s (Barton and Treadwell 1978) and by the 1980s there existed conferences, associations, and journals devoted to marketing higher education (Carrocci 2009, 7). Today, these conferences and associations continue to grow while an industry in consultancies devoted to higher education marketing has flourished alongside them. Nothing is more telling about the importance of marketing, though, than the creation of the Higher Education Chief Marketing Officer (CMO), a title that began to burgeon only in the last 10 years (Glazer and Korn 2012). These high-paid executives, many of whom come out of corporate marketing backgrounds, are tasked to sell the university, but they are also hired to create and solidify the institution's brand, or identity, a term more accepted within higher education (Toor 2002).

Whether called identity or branding, the creation of an instantly recognizable symbol, image, and mythology is essential to the marketing process (Sargeant and Ford 2007; Goldman and Papson 1996). In much the same way Disney is conceived of as "magic," colleges are "unconventional" (Reed College) or "independent" (Brown) or "intellectual" (University of Chicago) (Forbes n.d.). American University's (AU's) "Wonk" campaign is a recent extensive (and expensive) example of the lengths to which universities are moving toward branding. Started in 2011, this branding effort plays on the colloquialism of the policy wonk-a term appropriate for a university based in Washington D.C. It also aligns with the growth of "nerd culture," made hip by things like the success of Silicon Valley computer "nerds" and the popularity of events like Comic-Con, a conference devoted to all things comics-based. In sum, "Wonk" defines the university as smart, but one that doesn't take itself too seriously. While the campaign has met with significant backlash from alumni (Gibson 2014), the language continues to appear in marketing materials. This may, in part, be due to the cost of the Wonk campaign: AU reportedly spent $\$ 550,000$ on brand development and on the initial launch (Kelly 2013), and materials for the university were some of the most expensive analyzed as part of this study. One piece of direct mail was a 106-page book-the largest by far-that looked more like a highly designed fashion catalog than a view book for an institution of higher learning. The school also sent personalized four-colour brochures customized with student's names: "Hello! Susan. Here's the information you requested on mathematics." This piece of mail contained the name, phone number, and email address of a representative who can help with the admissions process, displayed next to their picture, making the document feel still more personal. Lastly, and important to this discussion, internships are integral to the university's brand message. Among the materials sent from AU were over-sized postcards stating, "Study at a wellconnected University, ranked first in the nation for internships by U.S. News \& World Report."

Creating a university brand identity is necessary because prospective students need to differentiate one school from another in an environment where schools look alike and, for many, the product cannot be sampled before purchase (Balmer, Liao and Wang 2010; Anctil 2008; Sung and Yang 2008). Further, university marketing is more complex than for typical brand marketers (Waeraas and Solbakk 2008). First, there is a limited window of opportunity-typically six months to a year-within which to sell the product, and second, students and parents are making this decision with significant emotional investments attached. Because of this, higher education marketers must reach prospects with compelling sales messages in intrusive ways. Therefore, if a university's brand is based on athletics, academics will be promoted on an equal footing with sports. An example from my study is a postcard from a major state school that shows a football mascot teaching in front of a classroom, an image that grabs attention because of its cognitive dissonance. Similarly, if a school promotes career preparation, they demonstrate 
that in marketing materials. I share some examples in the analysis below. Using attributes other than academics to sell an institution is not unusual. Except for the most elite schools, academics are promoted side-by-side with sports, the bucolic setting, and career preparation (Hartley and Morphew 2008).

\section{Marketing Universities Through Internships}

\subsection{Research Background and Methodology}

In 2011 I began researching the marketing of higher education as part of a popular book project aimed at educating parents about how universities use promotion during the search process, a topic of particular interest since I am a former marketer and the parent of a high school student. Working with a consultant who advises students on how to get into a university, we examined the environment that ignited the proliferation of higher education marketing, including the widening demographics for college students, the growth in for-profit institutions, the rising expenditures in marketing costs, and the messaging used to attract prospects. Research consisted of multiple methods-participant observation, auto-ethnography, and content analysis. Integral to that project, and the content analysis here, is the examination of direct marketing materials from institutions of higher learning.

To ascertain what messages were being presented to prospective students and their parents, I attended fairs for high school students needing preparation to get into college and college fairs attended by dozens of colleges from around the country. ${ }^{5}$ At these events I added my name to mailing lists as a parent of a high school student and in turn received dozens of emails and pieces of direct mail asking me first to visit the college and later to apply to colleges because I was "such a good candidate." I received messages that sold the institutions based on the availability of scholarships or the percentage of students who had gotten jobs, as well as faculty accomplishments. Some of the most sophisticated, funny, and amenities-based marketing that I received was from Towson University, including a rap video in one email and a video in another email from the university president saying that I had been accepted into the school. The offer was later rescinded with an email stating: "Although you did not apply and you are not admitted to Towson University, we hope that you will consider us in the future as your college choice."

While universities move toward promotion online, direct mail continues to be the predominant method for marketing. ${ }^{7}$ Therefore, to supplement the direct mail I acquired, I asked two high school students to save the mailings they received from universities around the country. I chose these students because they were going to competitive schools, one in New York City and one in the Washington D.C. area. They also had high SAT scores, which is important because universities send direct mail to students based on their test score. The higher the score, the more mail a student can expect to receive.

\footnotetext{
${ }^{5} \mathrm{An}$ industry has built up around preparing high school students to get into college, including test preparation companies, companies run by former admissions officers working with high school students to develop their résumé starting in their sophomore year, and multiple volunteer organizations.

${ }^{6}$ While I signed up as a parent of a student from Bronx Science (which is true), the systems only recognized me as a student. Also, I registered as being connected to Bronx Science because it is one of the top New York City high schools, and it was likely to induce more interest on the part of universities.

${ }^{7}$ It might seem surprising that direct mail, which is expensive to produce and to send, is still being widely used to target this young demographic that spends significant time online. However, marketers find that catalogs in particular enable them to "break through the clutter." Moreover synergy exists between catalogue readership and digital marketing (Holmes 2014) - people view products in print then move to digital formats for more information and to purchase.
} 
Working with an assistant, we sorted the materials and discovered that most schools began their marketing pitch with an almost identical letter that provides students with a user name and password, which they can use to go online and fill out an e-quiz, presumably to find a strong connection between the student and the school. The mailings also contain a smaller piece of paper with a space to fill out the student's name and phone number, and an envelope so they can return this information via snail mail if they do not want to go online. Alternatively, universities send postcards with a business reply card or ask students to go online to a special website that the school has created with the student's name (Naomi.xyzu.edu). The primary goal of these mailings is to get the student to respond so that the university can capture the student's information and add them to their official mailing list, enabling the school to send more descriptive content once the student demonstrates interest. ${ }^{8}$

These direct marketing pieces initiate the sales process. However, it is personal selling and the opportunity to experience the product that is most likely to complete the sale. Thus, at the beginning of senior year, universities connect with high school students in three ways: college admissions officers hold in-school meetings (Toor 2002), colleges participate in college fairs or hold individualized events at a local hotel, and students are invited for an on-site visit-either an open house or an "overnight experience." These events are heavily promoted through postcard mailings to entice students to sample the university.

In all, we received more than a thousand pieces of mail with as many as a dozen pieces coming from the same institution. Boston University, for example, sent 11 pieces of mail to one student including letters, postcards, booklets on financial aid, and a view book. Some sent university magazines; others used postcards, a series of postcards or postcards in a single envelope. Many schools sent elaborate view books, beautiful catalogs that present key attributes, like the diversity of students, types of majors, financial aid, successful faculty and alumni, and career preparation (Hartley and Morphew 2008). These books are widely used by universities and they are the most important marketing tool next to the on-campus visit (Klassen 2000).

Some culling was done in order to arrive at the final sample set. Initial postcards and letters, which asked the recipient to contact the university or to attend an open house, are "call to action" marketing and were not included in the sample because they did not mention attributes or benefits. After eliminating these mailings, 97 pieces from 92 different institutions remained for analysis. Most of these pieces were either view books or brochures of varying sizes, though one school sent a newspaper and another a deck of cards describing aspects of the school. Six postcards were included in the analysis as they did not contain a "call to action," but rather presented university attributes. In total, 84 marketing pieces-87 percent-contain some mention of internships.

\subsection{Internship Effect-Learning or Debt}

In university marketing materials, internships are presented either as part of career building, or as experiential or co-op learning. They are offered in relationship to careers in more than half of the pieces (57 percent), while experiential learning was the focus in 30 percent of the pieces analyzed. We found this distinction to be helpful in that it highlights the extent to which the university promotes higher education as a stepping stone to employment versus an institution promoting knowledge acquisition supplemented with "real world" experiences. For example, career-building schools make claims such as "...you and your parents want your college experience to provide you with the tools you need for life after college. You need to have a

\footnotetext{
${ }^{8}$ Companies, in this case universities, buy mailing lists from list brokers or other institutions such as the testing companies. The universities do not have access to the names until a student contacts them directly.
} 
résumé with internships and/or field experiences that will enable you to walk into a job interview and land that first job" (College of Saint Rose), or "Punch up your résumé and polish up your career credentials through experiential learning. Who knows? You may even parlay your parttime internships into full-time employment" (Rutgers University, emphasis in the original). While Northeastern-an institution well known for its co-operative experiences-promotes its programs as "the integration of study and practice, creating an unparalleled way to learn." The former seems to promote college as something to get through simply as a path to a career; the latter is a journey of acquiring knowledge. We will look into these ideas more deeply here.

First, internships discussed as part of career building were presented in a number of different ways. Sometimes this was a simple line of copy. More often, however, internship information appeared as part of a two-page spread highlighting the university's career office. Included in this content would be how the university could help students acquire internships by providing access to databases or career counselling sessions or workshops. The level of importance placed on this is also evident in universities creating easily remembered URLs for the career office, such as careers. villanova.edu.

Location, access to expert faculty, and the specific internships the university could provide are used to differentiate a school's career-building internships. In terms of location, for example, Florida International University promoted its Miami location as having "amazing internships and potential careers-as well as countless opportunities for entertainment, arts, culture, recreation, restaurants, night life, and just plain fun!" More typically, New York University, the University of Houston, University of Southern California, Pomona College, University of Albany, and Emory promote the benefits of being in a large city and use that as a way to highlight their access to top-level internships. An example of promoting faculty experts and the types of internships available was a strategy used by Manhattan Marymount College (MMC):

An average MMC class includes just 18 students, giving you direct access to faculty who are experts in their fields. Learn from New York's finest authors, artists, entrepreneurs, economists, and performers, as they connect you to opportunities across the city. That includes some of the country's most interesting internships at places like Bravo, Citigroup, Versace, and the New York City Ballet. MMC internships give you a chance to apply what you've learned in the classroom in the real world of work.

Note here the list of companies promoted. Three out of four are in the media or glamour industries. If universities used this tactic of listing specific internships, entertainment-oriented companies were always included. Here are a couple typical examples:

Make professional connections and intern in New York City. St. John's students have interned at a wide range of organizations, including Madison Square Garden, U.S. Secret Service, Estee Lauder, Morgan Stanley, MTV, New York Mets, SONY and Time Inc.

Recent LIU Post internships placements include: Museum of Natural History, CHANEL, St. Jude's Children's Hospital, United Nations, New York Times, Z100. Our students earn an average of $\$ 2,500-\$ 4,000$ per semester through internships and co-ops.

What is disturbing about this last piece is the line that suggests students will earn a salary through the internships listed. I know from my own experience that these "glamour field" internships are not paid opportunities. This is not to say that students never make money from internships. In some cases they do. However payment comes from the well-endowed and prestigious university, not the hiring company. Hamilton College boasts its "larger-than-average Career Center staff, with a larger than average budget," which enables the college to financially support 55 students who pursue unpaid internships. Similarly, the University of Chicago promotes the Jeff Metcalf Internship Program, which "provides paid, substantive internships 
exclusively to UChicago students." Tufts also notes in their materials that they have grant funding to support full-time unpaid summer internships.

Additionally, statistics and alumni-particularly those in cultural industry careers-help to sell the university internship experience. Many schools listed the number of opportunities they had available (one school claiming as many as 1,500 ) as well as the percentage of students who had done one or more internships while at school. Villanova took this farther than any other university. Its view book included a chart called "Class of 2011: Internship statistics." This information was broken down by field of study and categorized into students with one internship, and students with two or more internships. Looking at the "all" internship line, 796 students did one internship and 362 did two internships or more. This is at a university where a class size is approximately 1,600 students, so nearly half the class participated in at least one internship. Among the statistics schools now quote is their ranking on the U.S. News \& World Report internship list. Pace, for example, exclaims in bold type: "One of the top 10 schools in the nation for placing undergraduates in internships," a line shown next to a copy of U.S News \& World Report - a readily recognizable symbol of excellence for prospective students. Alumni, notably those in glamour fields, are also used to promote internships. The University of Miami, for example, shows pictures of successful alums and provides quotes about their internship experience. From Erin Moyer, supervising producer for NBC digital entertainment: "I quickly tapped resources available to me to land two incredible internships in California between my junior and senior year." Misericordia University's brochure takes this one step further, devoting a full-page picture of a recent graduate standing in Yankee Stadium with the following quote:

Misericordia prepared me from day one. I was able to graduate early and start my internship search. Within a few weeks, I had a call from the New York Yankees-Mario J. Oliveri, Sports Management, Consultant, Premium Sales and Service, New York Yankees.

The emphasis on career over college is quite evident in the quote noting that "I was able to graduate early" as an important benefit because it allowed the then-student to finish his academics quickly in favour of his career path.

One extreme case of placing career before traditional college learning is Champlain College. As it states on its Open House postcard: "Champlain College offers the best career-focused education in the country." The school touts its "Upside-Down Curriculum" in which students select their major and begin internships in their first year, an obvious point of pride for the school since it appears multiple times throughout their materials. In a booklet highlighting why students chose Champlain, one states, "The internship possibilities. The one thing I was looking for after college was a job, and since Champlain has such amazing opportunities for internships, it was a main reason I came here." The school also uses a series of foldout brochures, each with a different rule. One, called "Rule No. 67: Develop Your Skills for a Career. Develop Yourself for a Lifetime," explains that students will learn to "market yourself strategically." "Rule No. 16: At Champlain, You Won't Just Receive an Education, You'll Experience One" reiterates the school's career focus and claims, "Our students' internships offer exceptional immersion in their field, doing work that often leads to job offers before graduation."

In contrast, those universities that promote service learning or experiential learning strongly underscore knowledge acquisition over career development. Internships are most often discussed as some element of off-campus study or out-of-the-classroom experience, which also might include co-op, field study, or study abroad. Some examples include:

King's College: "Our curriculum extends beyond the classroom and students are encouraged to study abroad, intern and participate in service projects to broaden their experience." 
Smith: "Through innovative programs, cross-disciplinary learning, and internship and service opportunities outside the classroom, she will explore why and how to make her unique mark in the world."

Alfred University: "Many of our programs require internships, clinical experiences that may include professional cooperative agreements for paid employment and internships..."

It is easy to see how very different the language is in contrast to universities that focus on internships as steps in the career ladder. Experiences outside the classroom are seen as opportunities to translate in-classroom learning to the field. Moreover, the emphasis is on the student and not the value of the internship, as the Smith example demonstrates.

Schools with long histories of experiential learning primarily promote their cooperative learning experiences, though a few also mentioned internships as a possible option. For example, Rochester Institute of Technology has the fourth oldest co-op program and according to their materials, "is a world leader in experiential education with distinct and diverse opportunities to apply your education to real-world problems and projects." Rensselaer, another technically oriented university, also promotes experiential learning through co-ops and internships as "an essential component of a Rensselaer education." Other schools promoting experiential learning stress the value and advantages of a co-op experience over an internship. For example, Drexel University says in its brochure, "Co-op is a lot more than an internship. It's a full-time, six-month professional position (\$16,000 average 6-month salary)." Notes a postcard from Antioch: "[...] our students can design aspects of their own course of study and are required to work four terms in full-time positions at nonprofits, in business or in the arts [...]" Rice University promotes experiential learning by highlighting the research opportunities associated with these; internships are barely mentioned. And, of course, Northeastern University (NU) promotes its cooperative education because the school "is recognized as the world leader in co-op." One NU piece-“"The Husky Handbook"-explains co-op opportunities and how a student might put together their four or five year plan, which includes classes, study abroad, several service or research co-ops or internships, and professional/business co-ops or internships. The school also sends out Northeastern Magazine, which explains this process in more detail over four pages. The magazine notes, "A Northeastern education is built on the transformative power of study integrated with experience..."

In total, twelve pieces (13 percent) had no mentions of internship. Two of these were religious institutions, such as Albert A. List College of Jewish Studies and LaSalle University. Several were private, prestigious research institutions, such as Amherst, Haverford, Rice, Vanderbilt, and Union. ${ }^{9}$ Rather than career and résumé building, these institutions promoted experiential learning and academic research as well as community and public service programs that would "make a difference in the world." Beyond academics, they promote attributes that enable them to differentiate them from the competition, what marketers call the "unique selling proposition." For example, Vanderbilt University promotes quality, claiming it is "Among the Best" and using the following statistics to support its claim: National Universities $17^{\text {th }}$, Best Value $11^{\text {th }}$, Economic Diversity Among Top-Ranked Schools $17^{\text {th }}$ (U.S. News \& World Report) and Best Value Among Private Universities $18^{\text {th }}$ (Kiplinger). Alternatively, Haverford focuses on its core benefit-its identity-which is one of being a tight-knit learning community, and University of Maryland promotes its student body. Many of the others mentioned jobs or the possibility of a big paycheck, but not specifically internships.

\footnotetext{
${ }^{9}$ Union had a series of view books and I only saw one of four. It is possible that internships are mentioned in one of the other three pieces I did not receive.
} 
Tellingly, the overuse of internships as a marketing tool for universities has become recognized. Boston University's view book says as much when it notes: "The fact that an elite university like BU offers internships is nothing to get excited about." The piece goes on to explain that it is the type of internships, the Boston location, and international experiences that set them apart from other universities. Given the current analysis, that is not likely to be true.

\section{Media Internships: A Misleading Sales Tool}

Experiential learning, international internships, co-op learning, and paid internships provide valuable experience and aid students in integrating class learning with real world experience. These positions are atypical, however, in the media industry despite the emphasis placed on these positions in marketing for US universities. Both from my experience working in the media industry as well as directing the internship program in a media studies department, I rarely saw a student receive a job offer after completing an internship. This is so unusual I can count the number of job offers on one hand, and this is not because the students were unprepared or underqualified.

One student I advised as an intern is a perfect example. Debbie (not her real name) was a solid A student who had completed all her coursework with the intention of doing an internship with a private media company that produces a magazine as well as being a cutting-edge film and television production company. She worked with this organization for four months putting in almost full-time hours, and both she and the company were more than satisfied with the experience. The company told her they were hoping to have a job for her when the internship was over. They were waiting to hear about whether there was funding for the position. After waiting several weeks and putting off her job search because of expectations of having this position, the student was told there would not be a job opportunity (a year later, the company had half a billion dollars in investment funding).

Debbie couldn't help but get swept up in the tide that is the internship economy. Sixty-three percent of students graduating in 2012 completed an internship while 28 percent completed two or more (Smith 2012). Large companies made offers to 69 percent of students while small companies made offers to only 39 percent of their interns (ibid.). This is important to note because the media industry is increasingly made up of smaller companies-the type less likely to make a full-time offer. Debbie was also typical in that being female and having an unpaid internship within the media industry is the norm, a situation that is sparking increasing criticism (Schwartz 2013; Perlin 2011). Further, according to the National Association of Colleges and Employers, students who participate in unpaid internships-the kind media students are likely to have-are less likely to secure a full-time position than those who had paid positions. Moreover, unpaid interns were hired at a rate of 37 percent, while those who did no internship fared only slightly less well at 35 percent (Holland 2014).

Not doing an internship, though, is unrealistic. As Ross Perlin (2011) notes, "the internship ... has emerged victorious as the unrivalled gateway to white-collar work..." (xi). As true as that is for students generally, it is more so for those interested in positions in the cultural industries. Employers in this category expect multiple internships to be on a graduate's résumé. I know this not only from my corporate experience, but also because graduates call me after being out of school for a year or two wanting to know if they can come back just to do an internship because they did not do one while they were still a matriculated student. Add to this that the often suboptimal experience at a media internship (Frenette 2013; Frederick 1997) -as opposed to a cooperative experience-is exacerbated by the fact that the positions are unlikely to be paid. This is because there is an oversupply of cultural workers and wages are suppressed by professionals transferring fields, such as musicians writing movie scores (Hesmondhalgh 2012). As long as people (students and other cultural workers as well) are willing to work for free or 
close to it, there is no rationale for corporations to either hire more people or to hire them at a reasonable wage.

Bidding wages to zero is bad enough. Worse still, the internship economy has reduced the value of the experience because there is a glut of ex-interns in the marketplace. The obvious next step to sustain internship value is for "employers" to increase the amount of time students must work to differentiate their experience. We are already seeing this: O Magazine, for example, requires students to work eight-hour days, five days a week, and some sports teams require a six month commitment.

The overworking strategy has backfired, however. A number of lawsuits involving entertainment properties have generated significant publicity and led companies-and universities - to re-examine their internship programs. One of these cases involved Hearst, parent company of $O$ Magazine as well as other publications, which was sued by interns and no longer lists internship opportunities on their career website. The most well-known of these cases was the 2012 case against another magazine publisher, Condé Nast, which was brought by two former interns who claimed they were paid less than a dollar an hour for labour that was equivalent to that performed by full-time employees (Bridges 2013). In response, Condé Nast cancelled its internship program beginning in 2014. Other cases involved Fox Searchlight, NBCUniversal, and a number of music companies, including P. Diddy's Bad Boy Entertainment. These suits have forced companies to rethink how they manage their internship programs. In the case of WABC-TV, for example, student interns are now being paid, which is a good thing. However, according to Jackson Lewis, a law firm that specializes in employment issues and consults with universities on internship policy, companies are becoming more cautious about even implying that an internship is the gateway to a job. On its website, the firm advises companies that "if the program is unpaid, the business should strongly consider asking interns to sign an agreement acknowledging the educational nature of the program, the program is unpaid, and the internship is not a direct route to employment" (Jackson Lewis n.d.)

Given all this, it is not surprising that there has been a backlash. Greig de Peuter, Nicole Cohen, and Enda Brophy (2012) note that there is a nascent movement to fight against the unfair enterprise of the internship economy and its implications for workers more broadly. This appears to be more active outside of the United States, which may be because US graduates have unrealistic expectations about what the job market holds. According to the Accenture 2014 College Graduate Employment Survey, only 18 percent of recent graduates thought they would earn $\$ 25,000$ or less, while in truth more than double that number (41 percent of those who had graduated in 2012 and 2013) are earning salaries in that range. In addition, the number of underemployed college graduates working in jobs that do not require their degree increased from 41 percent in 2013 to 46 percent in 2014 (O'Shaughnessy 2014).

\section{Conclusion: Toward a More Valuable University/“Real World” Experience}

Not all off-campus experiences are created equal. A research internship at a prestigious medical institution or a co-operative learning experience at a tech lab is not the same as an internship at MTV or Sony records or The Maury Povich Show. The former provide opportunities for students to expand their learning, enhance their classroom knowledge, and receive a salary, sometimes a very substantial salary. The latter more often may not. Even so, it is these glamour industry opportunities that are used to market higher education because they so appeal to the target prospect.

Misleadingly, internships in media and elsewhere are presented as the gateway to full-time employment. I say misleading because there is little evidence that an internship will lead to a job. In fact, companies are being advised to make sure that students know an unpaid internship is in no way a guarantee of a job offer, yet colleges and universities are doing the oppositepromoting internships as the conduit to employment. 
Marketing universities, both local and less prominent colleges as well as prestigious institutions, as purveyors of internships positions higher education as an adjunct to corporate concerns. Internships have been intertwined with universities because they require college credit, turning institutions of higher learning into de facto temp agencies. Students "need" to have an internship, but they cannot get one, particularly from a major media company, unless they are getting college credit. Colleges, then, have to set up a system for students to access internships. This includes not only developing relationships with corporations that can hire students, but also helping students with résumés and interview skills and providing tools and guidance for developing a career plan. In the end, it is a limited win for the student who may get some training, a win for the college who makes money from the student, and a win-win-win for the corporation which gets free labour, and a workforce trained by the university and paid for by the student. And while students can do non-credit internships, these too vary widely and none of them are with the major media institutions that aid in significant résumé building.

Universities will certainly continue to promote themselves in more intrusive ways given today's competitive and corporatized landscape. It is unlikely, however, that the trend of using internships to market higher education can continue. This is because students assume they need to do an internship and therefore they assume the college will provide them access to these positions. In conjunction with that, promoting internships is an attribute-based strategy that does not distinguish one college from another and is unlikely to work long term; as internships are becoming increasingly the norm it will be branding-or access to co-ops or paid opportunities-that enables a school to differentiate itself from its competitors. What that means, then, is that internships will need to be financed either by companies paying students for their labour or by colleges providing funding for these experiences or a combination of the two. Finally, the internship economy for media companies is going through considerable adjustments given the recent lawsuits and increasing criticism and anti-internship activism This is already leading to an increasing number of paid internships for students, but also a shrinking number of opportunities in some areas, notably magazines. The full fallout from these changes is yet to be seen.

More important, however, is for universities and companies to reevaluate what a mutually beneficial relationship might look like. Experiential learning when integrated into class work can prove invaluable without making the experience about a career. For example, I teach a class in social innovation. I bring in executives from companies working on socially conscious marketing and have students develop marketing campaigns with the assistance of these people in the field. Students get to work on real world problems contextualized within a critical frame, the company gets insights from young adults who are typically their target audience, and the students present a final product to a working client. That is a true win-win-win. Universities should require this sort of in-classroom participation as quid pro quo for providing student interns. It puts the emphasis back on learning and critical thinking, and lessens the focus on careers and paycheques.

In doing this research, I was most impressed with Haverford University, an institution that does not talk about internships. Rather, the school makes its mission to develop the whole student within a community of learners: "Once again, it all comes down to community: a shared sense of values, challenging and inspiring each other in the joy of pursuing our ambitions, looking at life through the eyes of all others around us, and imagining ways to enrich a world of which we are all a part." That is what marketing higher education should be: presenting a vision of learning that nurtures the real product-the student.

\section{References}

Anctil, Eric. 2008. Recommendations for Selling Higher Education. ASHE Higher Education Report 34

(2): 89-98. 
Aronowitz, Stanley. 2001. The Knowledge Factory: Dismantling the Corporate University and Creating True Higher Learning. Boston: Beacon Press.

Balmer, John, Mei-Na Liao and W. Wang. 2010. Corporate Brand Identification and Corporate Brand Management: How Top Business Schools Do It. Journal of General Management 35 (4): 77-102.

Banet-Weiser, Sarah. 2013. Rate Your Knowledge: The Branded University. In The Routledge Companion to Advertising and Promotional Culture, edited by Matthew McAllister and Emily West, 298-312. New York: Routledge.

Barton, David and David Treadwell. 1978. Marketing: A Synthesis of Institutional Soul-Searching and Aggressiveness. In Marketing Higher Education, edited by D. Barton, Jr. 77-84. San Francisco: Jossey-Bass.

Belkin, Douglas, 2014. State Funding for Colleges Rebounds Still, Support Remains 11\% Below Five Years Ago in Real Dollars. The Wall Street Journal, January 20. Accessed June 1, 2014. http://online.wsj.com/news/articles/SB10001424052702304757004579333001917794012.

Bidwell, Allie. 2013. College Enrollment Falls for Second Year in a Row. U.S. News \& World Report, December 12. Accessed June 1, 2014. http://www.usnews.com/news/articles/2013/12/12/collegeenrollment-falls-for-second-year-in-a-row.

Bidwell, Allie. 2014. Colleges Get More Funds, but Rely on Tuition. U.S. News \& World Report, April 14. Accessed October 18, 2014. http://www.usnews.com/news/articles/2014/04/21/states-increase-highereducation-spending-rely-on-tuition-in-economic-recovery.

Black, Jim. 2008. The Branding of Higher Education. Accessed June 1, 2014. http://www.semworks.net/papers/wp The-Branding-of-Higher-Education.php.

Bok, Derek. 2004. Universities in the Marketplace: The Commercialization of Higher Education. Princeton: Princeton University Press.

Bousquet, Marc. 2008. How the University Works: Higher Education and the Low-Wage Nation. New York: New York University Press.

Bridges, Frances. 2013. How Condé Nast Should Have Fixed Its Internship Program. Forbes, August 11. Accessed August 17, 2015. http://www.forbes.com/sites/francesbridges/2013/11/08/how-conde-nastshould-have-fixed-the-internship-program/.

Brock, Bob. 2013. How Much Do You Spend on Advertising. Accessed June 1, 2014. http://emgonline.com/blog/2013/09/how-much-do-you-spend-on-advertising/.

Bunzel, David 2007. Universities Sell their Brands. Journal of Product and Brand Management 16 (2): 152-153.

Carrocci, Lindsay. 2009. Representing the Promotional University: Undergraduate Student Recruitment Strategies in Ontario 1997-2007. Master's Thesis, University of Western Ontario.

de Peuter, Greig, Nicole Cohen and Enda Brophy. 2012. Interns, Unite! You Have Nothing to LoseLiterally. Briarpatch, November 9, 8-12.

Forbes. n.d. 10 Colleges that are Great Brands. Accessed June 1, 2014. http://www.forbes.com/pictures/eikh45ejjd/babson-college-babson-park-mass/.

Frederick, Jim. 1997. Internment Camp: The Intern Economy and the Culture Trust. The Baffler 9, 51-58.

Frenette, Alexandre. 2013. Marketing the Intern Economy: Role and Career Challenges of the Music Industry Intern. Work and Occupations 40 (4): 364-397.

Gibson, Carter. 2014. AU Needs To "Kill its Darling" WONK, and it Just Might. Accessed June 1, 2014. http://inthecapital.streetwise.co/2014/03/10/american-university-why-au-needs-to-end-its-wonkcampaign/.

Glazer, Emily and Melissa Korn. 2012. Marketing Pros: Big Brand on Campus: Under Pressure, Universities Hire Outsiders to Advise on Identity, Admissions Brochures, Twitter Feeds. Wall Street Journal, August 15. Accessed January 15, 2013. http://online.wsj.com/news/articles/SB10000872396390444233104577591171686709792.

Goldman, Robert and Stephen Papson. 1996. Sign Wars: The Cluttered Landscape of Advertising. New York: Guilford Press.

Hartley, Matthew and Christopher Morphew. 2008. What's Being Sold and To What End? A Content Analysis of College Viewbooks The Journal of Higher Education, 79 (6): 671-691.

Hearn, Alison. 2010. "Through the Looking Glass": The Promotional University 2.0. In Blowing Up the Brand: Critical Perspectives on Promotional Culture, edited by Melissa Aronczyk and Devon Powers, 195-218. New York: Peter Lang. 
Heller, Donald. 2011. The States and Public Higher Education Policy: Affordability, Access, and Accountability. Baltimore: Johns Hopkins University Press.

Hesmondhalgh, David. 2012. The Cultural Industries. Thousand Oaks: Sage Publications.

Holland, Kelley. 2014. That Unpaid Internship May Have Been a Waste of Time. CNBC, February 3. Accessed May 15, 2014. http://www.cnbc.com/id/101378307.

Holmes, Elizabeth. 2014. Why Online Retailers Like Bonobos, Boden, Athleta Mail So Many Catalogs: Shoppers Spend More Online After Browsing through Lavish Print Spreads. Wall Street Journal, April 16. Accessed April 16, 2014. http://www.wsj.com/articles/SB10001424052702304311204579505532568168984.

Howe, Neil. 2014. The Unhappy Rise of the Millennial Intern. Forbes, April 22. Accessed February 20, 2015. http://www.forbes.com/sites/realspin/2014/04/22/the-unhappy-rise-of-the-millennial-intern/.

Jackson/Lewis. 2014. Wage and Hour Considerations with Interns. Accessed May 30, 2014. http://www.jacksonlewis.com/resources.php?NewsID=4848.

Kamenetz, Anya. 2006. Generation Debt: How Our Future Was Sold Out for Student Loans, Bad Jobs, No Benefits, and Tax Cuts for Rich Geezers-And How to Fight Back. New York: Riverhead Trade.

Kelly, Kim. 2013. 10 Awesome Education-Related Advertising \& Marketing Campaigns of 2012. Accessed October 22, 2014. http://sparkroom.com/blog/2013/01/10-awesome-education-related-advertisingmarketing-campaigns-of-2012/.

Kirp, David. 2004. Shakespeare, Einstein, and the Bottom Line: The Marketing of Higher Education. Cambridge: Harvard University Press.

Klassen, Michael. 2000. Lots of Fun, Not Much Work, and No Hassles: Marketing Images of Higher Education. Journal of Marketing for Higher Education 10 (2): 11-26.

Knouse, Stephen, John Tanner and Elizabeth Harris. 1999. The Relation of College Internships, College Performance, and Subsequent Job Opportunity. Journal of Employment Counseling 36 (1): 35-43.

Lay-Hwa, Jana. 2011. Engaging the Student as a Customer: A Relationship Marketing Approach. Bowden Marketing Education Review 21 (3): 211-228.

Lowrie, Anthony. 2007. Branding Higher Education: Equivalence and Difference in Developing Identity. Journal of Business Research 60 (9): 990-999.

Meredith, Marc. 2004. Why Do Universities Compete in the Ratings Game? An Empirical Analysis of the Effects of the US News and World Report College Rankings. Research in Higher Education 45 (5): 443-461.

Miley, Melissa. 2009. Universities Finally Espousing Branding. Advertising Age 80 (20): 6.

Mills, Nicolaus. 2012. The Corporatization of Higher Education. Dissent, Fall, 6-9.

Monks, James and Ronald G. Ehrenberg. 1999. The Impact of US News and World Report College Rankings on Admission Outcomes and Pricing Decisions at Selective Private Institutions. NBER Working Paper No. 7227.

Naidoo, Rajani, Avi Shankar and Ekant Veer. 2011. The Consumerist Turn in Higher Education: Policy Aspirations and Outcomes. Journal of Marketing Management 27 (11-12): 1142-1162.

Natale, Samuel and Caroline Doran. 2012. Marketization of Education: An Ethical Dilemma. Journal of Business Ethics 105 (2): 187-196.

Noel-Levitz. 2013. Cost of Recruiting an Undergraduate Report. Accessed June 1, 2014. https://www.noellevitz.com/papers-research-higher-education/2013/2013-cost-of-recruiting-anundergraduate-student-report.

O'Shaughnessy, Lynn. 2014. New College Grads Too Optimistic About Job Prospects. CBS MoneyWatch, May 8. Accessed May 15, 2014. http://www.cbsnews.com/news/new-college-grads-toooptimistic-about-job-prospects/.

Perlin, Ross. 2011. Intern Nation: How to Earn Nothing and Learn Little in the Brave New Economy. New York: Verso.

Rampell, Claudia. 2013. It Takes a B.A. to Find a Job as a File Clerk. New York Times, February 20, A1.

Reimann, Martin, Oliver Schilke and Jacquelyn S. Thomas. 2008. Toward an Understanding of Industry Commoditization: Its Nature and Role in Evolving Marketing Competition. International Journal of Research in Marketing 27 (2): 188-97.

Sargeant, Adrian and John B. Ford. 2007. The Power of Brands. Stanford Social Innovation Review 5 (1): 41-47.

Schwartz, Madeleine. 2013. Opportunity Costs: The True Price of Internships. Dissent Magazine Winter. http://www.dissentmagazine.org/article/opportunity-costs-the-true-price-of-internships. 
Shoenfelt, Elizabeth L., Nancy J. Stone and Janet L. Kottke. 2013. Internships: An Established Mechanism for Increasing Employability. Industrial and Organizational Psychology, 6 (1): 24-27.

Slaughter, Sheila and Larry Leslie. 1997. Academic Capitalism: Politics, Policies and the Entrepreneurial University. Baltimore: The Johns Hopkins University Press.

Smith, Jacquelyn. 2012. Internships: The New Interview. Accessed June 1, 2014. http://blogsimages.forbes.com/jacquelynsmith/files/2012/12/internshipsinfographic.jpg.

Steck, Henry. 2003. Corporatization of the University: Seeking Conceptual Clarity. Annals of the American Academy of Political and Social Science, 585: 66-83.

Sung, Minjung and Sung-Un Yang. 2008. Toward the Model of University Image: The Influence of Brand Personality, External Prestige, and Reputation. Journal of Public Relations Research 20 (4): 357-376.

Toor, Rachel. 2002. Admissions Confidential: An Insider's Account of the Elite College Selection Process. New York: St. Martin's Griffin.

Tuchman, Gaye. 2009. Wannabe U: Inside the Corporate University. Chicago: University of Chicago Press.

Twitchell, James. 2005. Branded Nation: The Marketing of Megachurch, College Inc., and Museumworld. New York: Simon \& Schuster.

U.S. Department of Education, National Center for Education Statistics. n.d. Back to School Statistics, 2012. Accessed May 2, 2013. http://nces.ed.gov/fastfacts/display.asp?id=372.

U.S. Department of Education, National Center for Education Statistics. (2013). Digest of Education Statistics, 2012 (NCES 2014-015). Accessed January 26, 2012. http://nces.ed.gov/fastfacts/display.asp?id=76.

Waeraas, Arild and Marianne N. Solbakk. 2008. Defining the Essence of a University: Lessons from Higher Education Branding. Higher Education 57 (4): 449-462.

Washburn, Jennifer. 2006. University Inc.: The Corporate Corruption of Higher Education. New York: Basic Books.

WICHE (Western Interstate Commission for Higher Education). 2012. Knocking at the College Door: Projections of High School Graduates. Accessed June 1, 2014. http://www.wiche.edu/info/publications/knocking-8th/ch2.pdf.

Woodhouse, Howard. 2009. Selling Out: Academic Freedom and the Corporate Market. Durham: Acumen Publishing.

\section{About the Author}

\section{Mara Einstein}

Mara Einstein has been working in or writing about the media industry for more than 25 years. She is the author of Compassion, Inc.: How Corporate America Blurs the Line Between What We Buy, Who We Are and Those We Help (University of California Press 2012), which examines the growing trend of promoting and selling consumer products as a means to fund social causes and effective social change. This builds on her continuing research into the effects of consumerism on social and cultural institutions, ideas considered at length in her last book, Brands of Faith: Marketing Religion in a Commercial Age (Routledge 2007), a critique of promoting religion. She has a PhD in Media Ecology from New York University, an MBA from the Kellogg Graduate School of Management at Northwestern, and a BFA in theatre performance from Boston University. She is currently working on a new book entitled Black Ops Advertising: Native Advertising, Content Marketing and the Covert World of the Digital Sell (O/R Books 2016). 